\title{
Five supposedly well-known species of Leptogium section Mallotium
}

\author{
Kitaura $\mathbf{M J}^{\mathbf{1}^{*}}$, Marcelli MP ${ }^{2}$, Jungbluth $\mathbf{P}^{1}$ and Hora $\mathbf{B R}^{1}$ \\ ${ }^{1}$ UNESP, Instituto de Biociências, Depto de Botânica, Distrito de Rubião Jr., Caixa Postal 510, Botucatu/SP, CEP \\ 18618-970, Brazil (junjimjk@gmail.com). \\ ${ }_{2}^{2}$ Instituto de Botânica, Núcleo de Pesquisa em Micologia, Caixa Postal 68041, São Paulo/SP, CEP 04045-972, Brazil.
}

Kitaura MJ, Marcelli MP, Jungbluth P, Hora BR 2013 - Five supposedly well-known species of Leptogium section Mallotium. Mycosphere 4(3), 520-530, Doi 10.5943/mycosphere/4/3/6

\begin{abstract}
The revision and detailed description of type specimens of five supposedly well-known hairy Leptogium species revealed taxonomically relevant new data. Both holotype and isotype of $L$. capense are a mixture of species and a new lectotype is designated. A new isotype of $L$. decipiens was found at $\mathrm{E}$. The protologue of L. inversum mentioned marginal apothecia but the holotype has just laminal and sub-marginal apothecia. The lectotype duplicate of $L$. resupinans is not really a fragment of the lectotype and must be considered as syntype. The apothecia of L. scrobiculatum are described for the first time.
\end{abstract}

Key words - Collemataceae - cylindrical cells - hairs - type material

\section{Introduction}

Leptogium is a genus of Collemataceae present in different habitats in the world (Sierk 1964). Perhaps due to its gelatinous appearance when humid, the species were considered very plastic (Jørgensen 1973, Awasthi \& Akhtar 1977, Swinscow \& Krog 1988). However, Jorgensen (1997), nowadays the recognized major authority in the genus, gradually changed his mind about the plasticity and relevance of morphological characters and turned important some minor differences such as the surface relief, the colour of the thallus and type of isidia. Recently, new species differentiated by this new interpretation appeared (Jørgensen \& Kashiwadani 2008, Jørgensen \& Olley 2010, Kitaura \& Marcelli 2013) in a process extended to other lichen groups of tropical lichens as species of Parmeliaceae (e.g., Canêz \& Marcelli 2010) and Pyxinaceae (e.g., Jungbluth et al.2011).

The taxonomy and nomenclature of Leptogium have been poorly understood (Jørgensen 2002) and it is very common that species are known only by their original descriptions and without mention of the type material. In fact, many types are "lost" in the species author's herbaria and perhaps many of them will not be recovered. Furthermore, those descriptions, sufficient in the time when they were made, are nowadays so simple and short that they could embrace a number of different species. This is one of the reasons why it is very common that Leptogium species are identified all over the world and even published as "in authors' sense", turning many taxa pantropical or even cosmopoliton.

As a complication for interpreting species circumscription, authors who described Leptogium species since the $19^{\text {th }}$ Century (e.g., Dodge, Malme, Sierk, Vainio, Nylander, 
Zahlbruckner, Verdon, Galloway, Jørgensen) based their descriptions upon a somehow different set of characters, complicating the comparison of descriptions (Cunha 2007, Kitaura 2012).

Moreover, a molecular work by Otálora et al. (2010) suggested that Leptogium species should be differentiated based on usually little used characteristics. Consequently, in order to understand the correct species circumscriptions, the genus needs a complete taxonomical revision to get descriptions based upon a reliable set of characteristics. Cunha (2007), Kitaura (2012) and Kitaura \& Marcelli (2012) developed a morphological/anatomical protocol to standardize descriptions of Leptogium species. The last version (Kitaura 2012) evaluated about 158 characteristics, in a clear demonstration that both thalli and ascomata internal and external morphology are far from simple structures, and that species can be efficiently differentiated and adequately described based on them.

The section Mallotium (hairy species) is the most studied in Leptogium and the only with a world key of identification (Jørgensen 1997). However, revisiting many types of this group, we still found remaining problems in descriptions and typification. This works deals with some of these species and presents the standardized descriptions based in our protocol.

\section{Material and methods}

This study is based on type specimens that were generously loaned from B, BM, E, H and S Herbaria. The descriptions, terminology and descriptive procedure follow the protocol of Kitaura (2012) and Kitaura \& Marcelli (2012, 2013).

The term duplicate of lectotype is utilized here to designate a true piece of the lectotype specimen. Although now the ICN uses the term isolectotype (McNeill et al. 2012), this may actually indicate a true piece of lectotype as well as any specimen of type collection; this is dangerous and misleading in our opinion, since we regularly, in an almost daily basis, confront mixed type collections and even mixed type material.

The apothecium was considered sessile when its base is immersed in the thallus, differing from the adnate apothecium, which has the base on the thallus. As in most lichens, any structure elevating the apothecia above the thallus is traditionally named a pedicel in Leptogium. However, in this genus the pedicel can be thalline in origin or made exclusively by the fungal tissue of the apothecia basis. The thalline pedicel is concolorous with the thallus and can be very elevated and even bullate, whereas the apothecial pedicel is beige or yellowish as the amphithecia and is usually shorter.

\section{The species}

Kitaura (2012) revised the types of 15 Leptogium species with hairs composed by cylindrical cells. We present below detailed descriptions and comments on the five types which revealed new findings or discrepancies to previous knowledge. The types of apothecial tissues were classified by the thickness pattern of the cellular wall, according Kitaura \& Marcelli (2013).

Leptogium capense P.M. Jørg. \& A.K. Wallace, Symbolae Botanicae Upsalienses 32: 113. 1997.

Figs 1-3

\section{Type}

South Africa, Cape Province, 24.I.1878, leg. P. MacOwan s/n. (lectotype designated here: specimen A of BM!; duplicates of lectotype: specimen B of BM! and specimen A of E!).

\section{Description}

Thallus grey to bluish grey with brownish margin under fluorescent light, opaque, mat; light grey or bluish with brown margins under the stereomicroscope. Lobes 4-7 mm wide, slightly overlapping, adpressed or attached in points, adnate; upper surface smooth to the naked eye, rugulose under 20x magnification; apices rotund, ascending and involute, smooth; lateral margin smooth, involute, flattened to slightly sinuous or undulate; lower side grey to bluish grey, smooth and hairy to the naked eye, velvet with agglutinated hairs under $20 \times$ magnification. Isidia and 


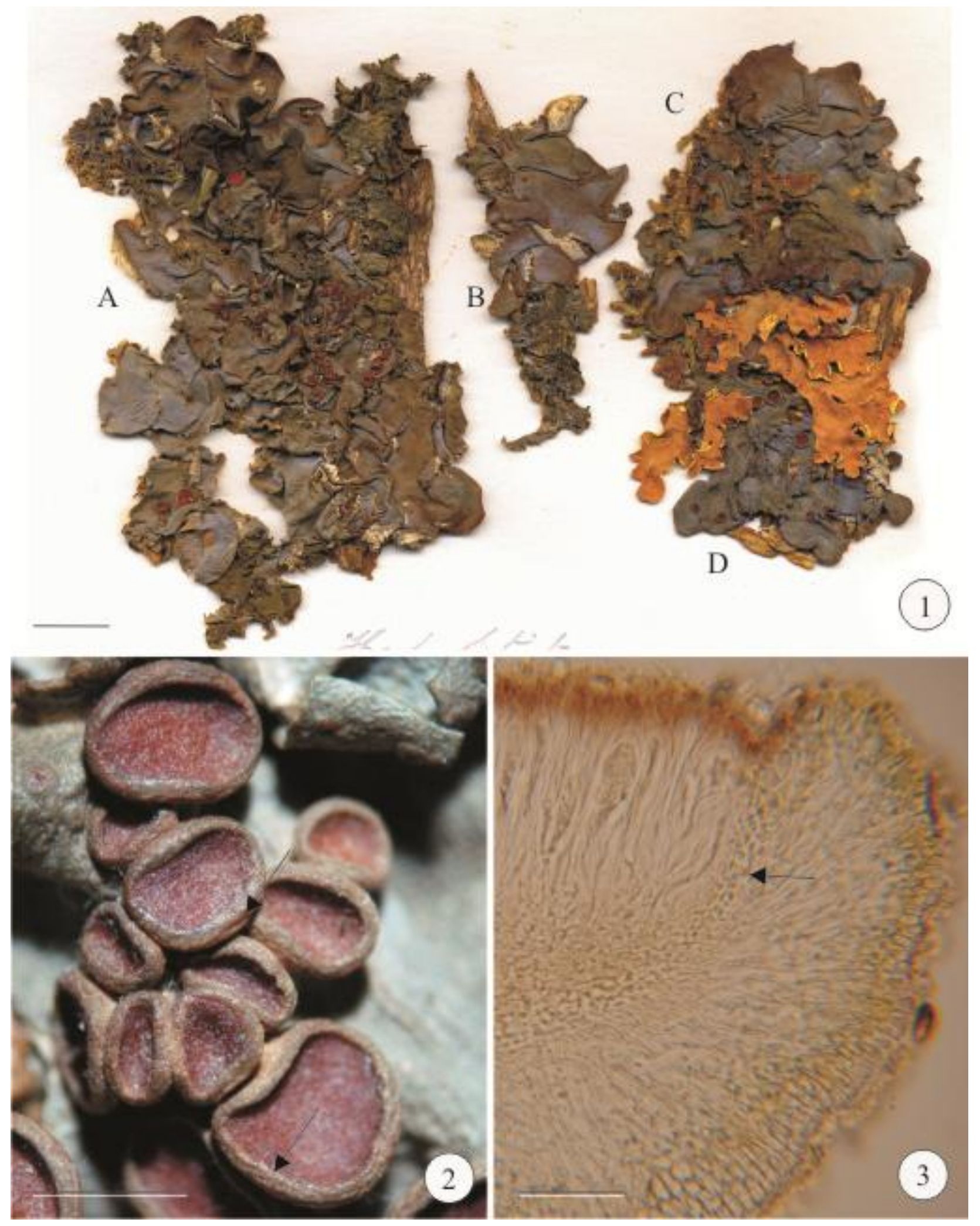

Figs 1-3 - Leptogium capense. 1 Fragment " $A$ " is the lectotype, " $B$ " is the duplicate of lectotype, "C" is L. cf. burnetiae and " $\mathrm{D}$ " is L. sessile. 2 Amphithecia with circular grooves (arrow). 3 Transverse section of apothecium (arrow $=$ parahymenial colloplectenchymatous). - Bars $1=1 \mathrm{~cm}$, $2=2 \mathrm{~mm}, 3=50 \mu \mathrm{m}$.

lobules absent. Thallus attached by hairs; rhizines absent; hapterons absent; hairs simple, more than $100 \mu \mathrm{m}$ (6-11 cylindrical cells) long, beige, restricted to the lower side, abundant to dense. 
Apothecia up to $2 \mathrm{~mm}$ diam., laminal, subpedicelate, disc flattened to cupuliform when older; margin browned or slightly yellow, smooth with cracks in older apothecia; amphithecia brown to yellow, smooth to the naked eye but with circular grooves under 10x magnification; base grey; corona absent; pedicel originated by the thallus, very short.

\section{Anatomy}

Thallus 80-170 $\mu \mathrm{m}$ thick, quadratic cells of the cortices 5-10 $\times 5 \mu \mathrm{m}$; columnar hyphae 2.5 $\mu \mathrm{m}$ thick, inclined, straight or sinuous, normally more than 4 cells long, abundant. Cyanobacteria blue, frequent, filaments with 8 or more elliptic cells; gelatinous matrix hyaline to greenish next to the cortex. Apothecia with hymenia 115-175 $\mu \mathrm{m}$ high; subhymenia 25-50 $\mu \mathrm{m}$ thick, hyaline to light yellow; hypothecia an angular colloplectenchymatous tissue 50-55 $\mu \mathrm{m}$ (4-5 cells) thick, hyaline; subhymenial paraplectenchymatous tissues absent; parahymenial tissues an angular colloplectenchyma continuous to hypothecia, $35 \mu \mathrm{m}$ (4 cells) thick at the base, $50 \mu \mathrm{m}$ ( 3 cells) thick at the apex; thalline exciples as tall as hymenia or higher, 5-15 $\mu \mathrm{m}(1-2$ cells $)$ thick at the apex, 10-25 $\mu \mathrm{m}$ ( 2 cells) thick at the middle, 25-50 $\mu \mathrm{m}$ (4-6 cells) thick at the base, paraplectenchymatous cells; basal paraplectenchymatous tissues 15-100 $\mu \mathrm{m}$ (2-9 cells) thick. Ascospores fusiform, 25-30 × 10-13 $\mu \mathrm{m}, 4-5 \times 2-3$ cells, apices acute, submuriform or little muriform. Pycnidia laminal or marginal, grey with brown ostioles; conidia bifusiform or bacilliform, 3.5-5.0 × 1.0-1.5 $\mu \mathrm{m}$.

\section{Comments}

Leptogium capense, from South Africa, is characterized by the rugulose upper surface, presence of circular grooves on the brownish amphithecia, hypothecia and parahymenial tissue composed by colloplectenchymatous cells and paraplectenchymatous thick thalline exciple.

Jørgensen (1997) indicated as holotype of $L$. capense material collected by a Mac Owen in 1887. However, the label in the BM material should be read as MacOwan (probably P. MacOwan, a mycologist who lived between 1830 and 1909 and studied material from South Africa, according the IPNI website) and the collection year is 1878 .

Furthermore, the MacOwan material is a mixed collection with certainly more than one specimen that might be referred as syntypes, of manner that a lectotype must be designated according the ICN (McNeill et al. 2012). The exsiccate is composed by different fragments that we indicated as "A", "B", "C" and "D". The specimens "A" and "B" have pieces of L. capense (with hairs and apothecia) mixed with fragments of $L$. cf. coralloideum (Meyen \& Flot.) Vain. that has a ridged, isidiate and not hairy surface. The specimen " $\mathrm{C}$ " is as hairy as those $L$. capense specimens of "A" and "B", but has isidia on the upper surface and can be named L. cf. burnetiae C.W. Dodge. Finally, the specimen " $D$ " has sessile apothecia on a naked thallus and is L. sessile Vain.

The syntype of Leptogium capense was pasted on the card and the lectotype was not separated of the other fragments. The type material can be destroyed if pulled of the card. The material deposited in E is certainly part of that same material in BM and has the same mixture of Leptogium capense and L. aff. burnetiae pieces. Jørgensen (1997) considered the material deposited in $\mathrm{G}$ an isotype; nevertheless, it was collected in a different expedition and might be considered just a paratype.

Leptogium decipiens P.M. Jørg., Flechten Follmann 237. 1995.

Figs $4-5$

\section{Type}

Chile, XII Region, Cerro Dorotea, next to Puerto Natales, in sandstone, 9.V.1940, leg. R. Santesson 8259 (holotype: S!; isotypes: UPS, E!).

\section{Description}

Thallus bluish to black, opaque, mat; bluish to brown with darkened margin when viewed in a stereomicroscope. Lobes to $4 \mathrm{~mm}$ wide, overlapping, attached in points, revolute; upper surface 
smooth to the naked eye, smooth to rugulose at magnification 20x; apices rounded, flattened or revolute, smooth or isidiate; lateral margin smooth, flattened or ascending and revolute, undulate and slightly sinuous; lower side bluish, pubescent when observed at different magnifications (margin usually naked). Isidia granular or cylindrical, smooth, $0.10-0.50 \times 0.05-0.10 \mathrm{~mm}$, usually simple to irregularly branched, erect, firm, concolorous with the thallus but with darkened apices; laminal, marginal and on the amphithecia; dense, abundant, the laminal usually granular and the marginal cylindrical and branched. Lobules absent. Fixation by the hairs; rhizines absent; hapterons absent; hairs simple, up to $100 \mu \mathrm{m}$ long, cream, usually on lower side, abundant, 6-10 cylindrical cells, agglutinated on center of lower side. Apothecia ca. $0.5 \mathrm{~mm}$ diam., laminal, subpedicelate, disc flattened; margin yellow to brown, smooth, granular isidiate; amphithecia yellow to brown, smooth to isidiate; corona absent; pedicel originated by the thallus, very short.

\section{Anatomy}

Thallus 50-75 $\mu \mathrm{m}$ thick, quadratic cells of upper cortex $5 \mu \mathrm{m}$ wide, quadratic cells of lower cortex $7.5 \times 5.0-7.5 \mu \mathrm{m}$; columnar hyphae $2.5 \mu \mathrm{m}$ thick, straight, $3-4$ cells. Cyanobacteria green or blue, frequent to abundant, an indeterminate number of the elliptical to spherical cells in the filament, $2.5 \times 2.5-4.0 \mu \mathrm{m}$; gelatinous matrix greenish in upper region and hyaline in lower region. Apothecia with hymenia 85-100 $\mu \mathrm{m}$ high; subhymenia 35-45 $\mu \mathrm{m}$ thick, yellow; hypothecia 37-45 $\mu \mathrm{m}$ thick, with an yellow angular colloplectenchyma at the base; subhymenial paraplectenchymatous tissues $25-40 \mu \mathrm{m}$ (ca. 4 cells) thick at the center; parahymenial tissues continuous to the subhymenial paraplectenchyma, 35-45 $\mu \mathrm{m}$ (ca. 6 cells) at the base, 65-70 $\mu \mathrm{m}$ (ca. 8 cells) at the apex; thalline exciples as tall as hymenia, 20-25 $\mu \mathrm{m}$ ( 3 cells) thick at the apex, 45-50 $\mu \mathrm{m}$ (4 cells) thick at the middle, 50-55 $\mu \mathrm{m}$ (6 cells) thick at the base; basal paraplectenchymatous tissues $10-40 \mu \mathrm{m}$ (2-4 cells) thick, covered by hairs. Ascospores fusiform, 20-37 $\times 8-12 \mu \mathrm{m}, 2-4 \times 1-2$ cells, apices acute or acuminated to obtuse, submuriform to transversally septate. Pycnidia laminal, concolorous with the thallus, brown ostiole; conidia bifusiform or bacilliform, 3.5-4.0 × 1.0-1.5 $\mu \mathrm{m}$.

\section{Comments}

Leptogium decipiens is a South American species characterized by the bluish thallus, upper surface with longitudinal light wrinkles, presence of granular to cylindrical isidia on the margin of apothecia, thick subhymenial paraplectenchymatous tissue and thick exciple thalline.

The type is muscicolous and probably has parts of different individuals. The thallus of $L$. decipiens is not as big as the thallus of $L$. capense and the type can be composed by a lot of specimens.

The species is very similar to the L. mandonii P.M. Jørg., but L. decipiens differs by the characteristics shown in Table 1 (Kitaura, 2012).

We found an isotype deposited in $\mathrm{E}$ that was not cited in the protologue (Galloway \& Jørgensen 1995).

Table 1 Differences between Leptogium decipiens and L. mandonii.

\begin{tabular}{|c|c|c|}
\hline & Leptogium decipiens & Leptogium mandonii \\
\hline Upper surface up to $20 \times$ magnification & Smooth to rugulose & Usually smooth \\
\hline Apices of lobes & $\begin{array}{l}\text { Flattened or revolute, smooth } \\
\text { to isidiate }\end{array}$ & $\begin{array}{l}\text { Flattened to involute, } \\
\text { crenulated }\end{array}$ \\
\hline Amphithecia & Isidiate & Smooth \\
\hline Subhymenial paraplectenchymatous tissue & $25-40 \mu \mathrm{m}$ thick at the center & Absent \\
\hline Parahymenial tissues & $\begin{array}{l}\text { Continuous to subhymenial } \\
\text { tissue, paraplectenchymatous }\end{array}$ & $\begin{array}{l}\text { Continuous to hypothecia, } \\
\text { collo- to } \\
\text { paraplectenchymatous }\end{array}$ \\
\hline Ascospores $(\mu \mathrm{m})$ & $20-37 \times 8-12$ & $25-33 \times 10-13$ \\
\hline
\end{tabular}



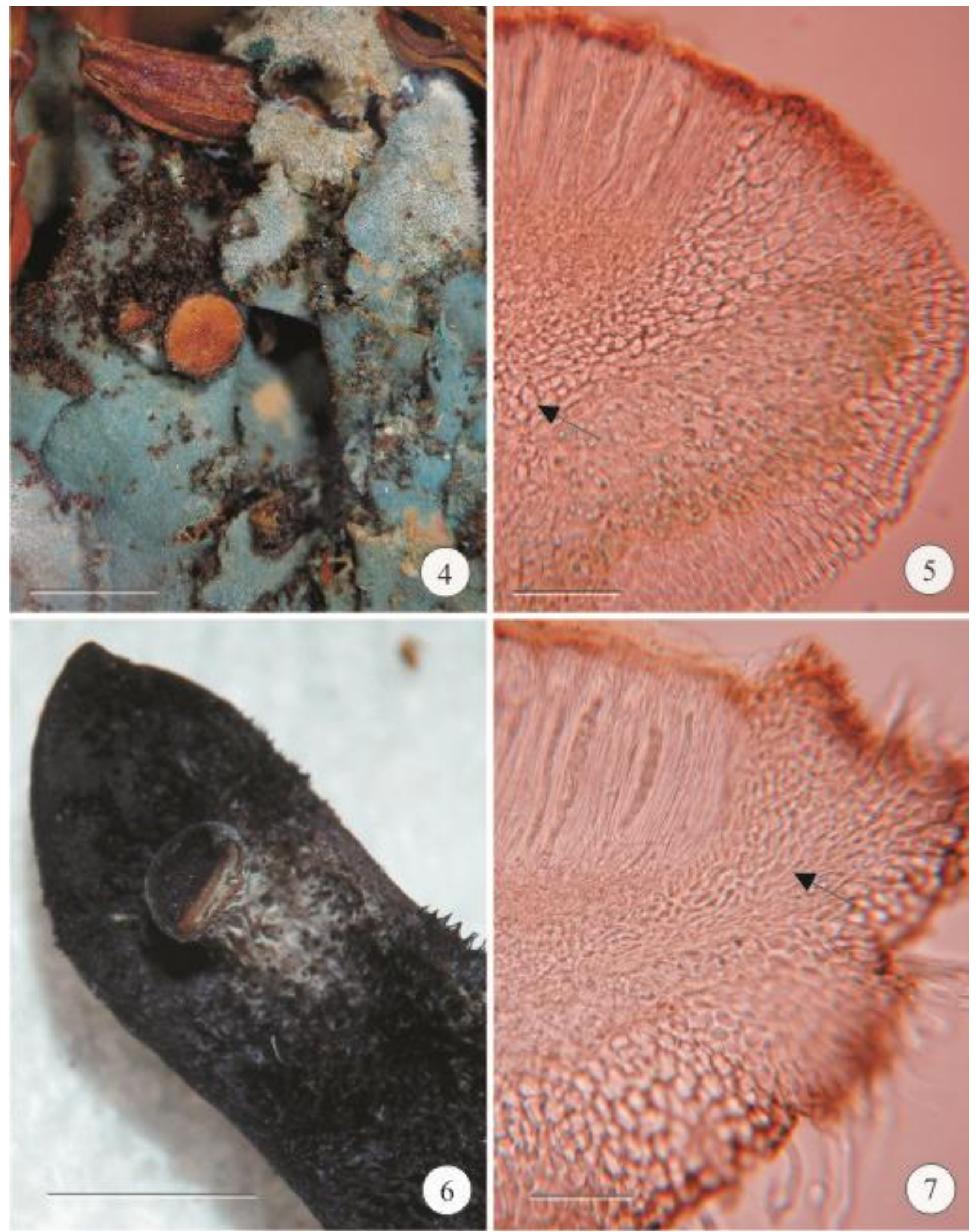

Figs 4-7 - Holotypes. 4, 5 Leptogium decipiens. 4 Apothecium with isidia on the margin. 5 Transversal section of apothecium (arrow $=$ paraplectenchymatous subhymenial tissue). 6, 7 Leptogium inversum. 6 Detail of laminal apothecium. 7 Transverse section of apothecium $($ arrow $=$ parahymenium composed by slightly elongated cells). Bars $4=1 \mathrm{~mm} ; 5,7=50 \mu \mathrm{m} ; 6=2 \mathrm{~mm}$. 
Type

Colombia, Meta, Cerro Nevado Del Sumapaz, 4070 m a.s.l., leg. A.M. Cleef 8135a (holotype: B!; isotype: $\mathrm{BG})$.

\section{Description}

Thallus dark brown to black (perhaps because of the herborization procedure), opaque, mat with a glossy part; dark brown to black with greenish grey spots (probably the original color of the thallus) under stereomicroscope. Laciniae $3 \mathrm{~mm}$ wide, overlapping, attached in points, adnate, upper surface smooth to the naked eye, slightly rugulose under $20 \times$ magnification; apices rotund, mainly revolute, smooth; lateral margin smooth, straight, strongly revolute; lower side greenish grey to dark brown, smooth and naked on the apices, pubescent on the other regions under different magnifications. Isidia and lobules absent. Thallus attached by hairs; rhizines absent; hapterons absent; hairs simple, more than $125 \mu \mathrm{m}$ long, cream to black, on the lower side, dense, abundant, ca. 6 cylindrical cells. Apothecia up to $1 \mathrm{~mm}$ diam., laminal to submarginal on lower surface, subpedicelate, disc flattened or cupuliform when older; margin concolorous with the thallus, pubescent, hairs similar to those on lower side; corona absent; pedicel originated by the thallus, very short.

\section{Anatomy}

Thallus $60 \mu \mathrm{m}$ thick, quadratic cells of upper cortex $10 \mu \mathrm{m}$ diam., quadratic cells of lower cortex $12 \times 10 \mu \mathrm{m}$; columnar hyphae $2.5 \mu \mathrm{m}$ thick, straight, 2 cells long. Cyanobacteria blue, frequent, filament with a not determinate number of elliptic cells 3.5-4.0 $\times 2.5 \mu \mathrm{m}$; gelatinous matrix scarce, hyaline. Apothecia with hymenia 150-170 $\mu \mathrm{m}$ high; subhymenia 20-30 $\mu \mathrm{m}$ thick, yellow; hypothecia 80-90 $\mu \mathrm{m}$ thick, hyaline, prosoplectenchymatous cells; subhymenial paraplectenchymatous tissues absent; parahymenial tissues continuous to hypothecia, 20-25 $\mu \mathrm{m}$ thick at the base, 90-100 $\mu \mathrm{m}$ thick at the apex, cells slightly elongated with thick walls; thalline exciples with pigmented cells, $7 / 8$ of the hymenium height, 20-30 $\mu \mathrm{m}$ (ca. 3 cells) thick at the apex, $90-100 \mu \mathrm{m}$ (ca. 7 cells) thick at the middle, 110-125 $\mu \mathrm{m}$ (ca. 7 cells) thick at the base; basal paraplectenchymatous tissues covered by thallus, 60-70 $\mu \mathrm{m}$ (ca. 4 cells) thick. Ascospores fusiform, 30-38(-50) × 10-13 $\mu \mathrm{m}, 4-6 \times 3-4$ cells, apices obtuse to acute, muriform. Pycnidia absent.

\section{Comments}

Described from Colombia, in northern South America, Leptogium inversum has a laciniate thallus with a typically cetrarioid appearance, as mentioned by Jørgensen (1997), and develops apothecia on the lower surface. The apothecium has prosoplectenchymatous hypothecium, parahymenium composed by slightly elongated cells with thick walls and pigmented exciple thalline.

The blackish colour of type specimen probably is consequence of a bad herborization that frequently occurs when Leptogium specimens are collected very humid and warmed for a fast drying: the cells can collapse and the colour of the thallus change.

In the protologue, the apothecia were described as marginal (Jørgensen 1997), but only laminal and sub-marginal apothecia were found on holotype. Furthermore, we found ascospores 30-38(-50) × 10-12 $\mu \mathrm{m}$, whereas Jørgensen (1997) mentioned very different measures [50-60 × $13-15 \mu \mathrm{m}]$.

Leptogium resupinans Nyl., Annales des Sciences Naturelles Botanique et Biologie Vegetale 15(4): 368. 1861.

Figs 8-9 


\section{Type}

Bolivia, in subalpinis, leg. Mandon. Herb W. Nylander (lectotype H-NYL 41416!; syntype: H-NYL 41301!).

\section{Description}

Thallus bluish grey or brownish beige, opaque, mat, bluish grey to brown under stereomicroscope. Lobes up to $4 \mathrm{~mm}$ wide, agglomerated, attached by the base, ascending to suberect (pressed material); the pubescent surface smooth under different magnifications; apices rotund, flattened to revolute, smooth to crenate; lateral margin smooth, revolute or involute, undulate and sinuous; the naked surface grey to bluish grey, smooth to the naked eye, smooth but with a few pubescent spots under $20 \times$ magnification. Isidia and lobules absent. Thallus attached by hairs; rhizines absent; hapterons absent; hairs $\geq 100 \mu \mathrm{m}$ long, cream, frequent to dense, number of cylindrical cells indeterminate (interwoven hairs). Apothecia up to $3 \mathrm{~mm}$ diam., laminal on the pubescent surface, subpedicelate, disc flattened to concave; margin yellow to white, smooth or denticulate to dentate, lobulate or pubescent, lobules on the margin are degraded; amphithecia concolorous, completely covered by hairs; corona absent or to very reduced in young apothecia; pedicel probably originated by the thallus, hairs on the pedicel, short.

\section{Anatomy}

Thallus up to $75 \mu \mathrm{m}$ thick, quadratic cells of both cortices 5.0-7.5 $\mu \mathrm{m}$ wide; columnar hyphae $2.5 \mu \mathrm{m}$ thick, straight, 3-4 cells long. Cyanobacteria bluish green to blue, frequent, filaments with indeterminate number of spherical cells $5 \mu \mathrm{m}$ diam.; gelatinous matrix scarce, green next the cortices and hyaline in the middle. Apothecia with hymenia 175-200 $\mu \mathrm{m} \mathrm{high;}$ subhymenia yellow 30-40 $\mu \mathrm{m}$ thick; hypothecia yellow 50-75 $\mu \mathrm{m}$ thick, elongated cells; subhymenial paraplectenchymatous tissues absent; parahymenial tissues continuous to hypothecia, composed by paraplectenchymatous cells smaller than amphithecial cells, $35-45 \mu \mathrm{m}$ (6-8 cells) thick at the base and apex; thalline exciples $7 / 8$ of the hymenia height, $65-75$ (ca. 4 cells) thick at the apex, 65-75 $\mu \mathrm{m}$ (5 cells) thick at the middle, 110-125 $\mu \mathrm{m}$ (6-7 cells) thick at the base; basal paraplectenchymatous tissues covered by hairs, 110-120 $\mu \mathrm{m}$ (7 cells) thick. Ascospores fusiform, 30-33 × 10-15 $\mu \mathrm{m}, 4-5 \times 2-3$ cells, apices acute, submuriform. Pycnidia laminal to marginal, brown; conidia bifusiform to bacilliform, 3.5-4.0 × 1.0-1.5 $\mu \mathrm{m}$.

\section{Comments}

The South American Bolivian Leptogium resupinans has one surface with arachnoid or interwoven hairs and the other glabrous and bluish. The apothecium is composed by the hypothecia with elongated cells, paraplectenchymatous parahymenium and thick thalline exciple.

Nylander (1861) utilized the word "resupinans" to indicate the presence of apothecia on lower surface, but Jørgensen (1975) and Swinscow \& Krog (1988) stated that the apothecia are on upper surface. Just two individuals were studied and the specimens were pressed during the herborization. We consider that it is not possible to establish the true position of the apothecia with analyze on this pressed material. Therefore, $L$. inversum is the only species with apothecia on lower surface (Jørgensen 1997) and differs from L. decipiens by the laciniate cetrarioid thallus.

The holotype was not indicated by Nylander (1861) in protologue, but when the material was revised by Jørgensen (1975), a lectotype (H-NYL 41416) and the duplicate of lectotype (HNYL 41301) were indicated. However, H-NYL 41301 is not part of H-NYL 41416 and it is not a duplicate of material. According to ICN (McNeill et al. 2012), the material H-NYL 41301 is just a syntype.

Leptogium scrobiculatum P.M. Jørg., Symbolae Botanicae Upsalienses 32: 123. 1997. Figs 10-11

\section{Type}

Peru, Ancash, Yungay, inroad Yungay-Llanguasmao, ca. 22 Km NE de Yungay, 26.II.1981, 

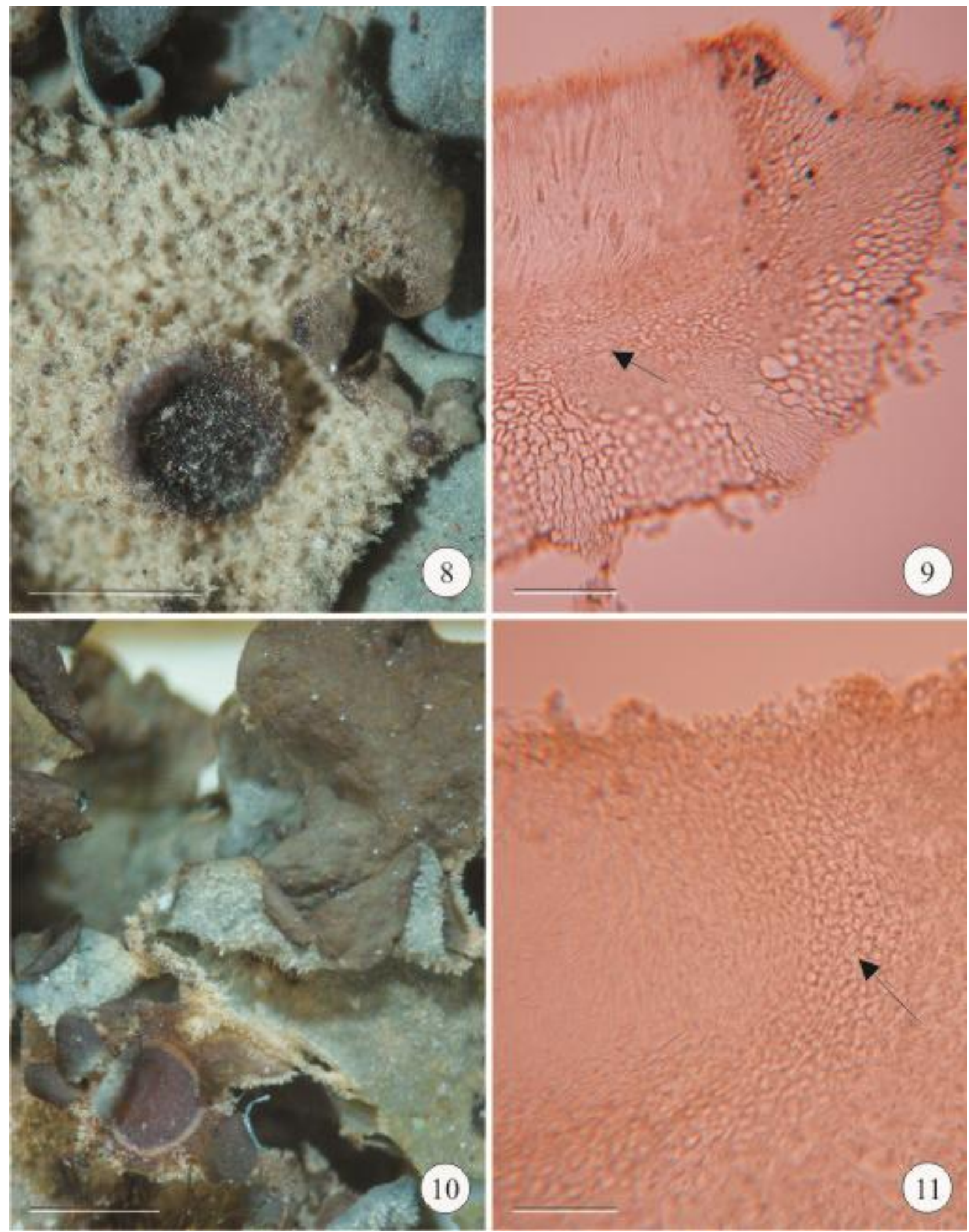

Figs 8-11 - Material types. 8, 9 Leptogium resupinans. 8 Surface with arachnoid or interwoven hairs. 9 Transversal section of apothecium (arrow = hypothecia with elongated cells). 10, 11 Leptogium scrobiculatum. 10 Morphological detail of apothecium. 11 Transverse section (arrow = colloplectenchymatous to paraplectenchymatous parahymenium). Bars $8,10=1 \mathrm{~mm} ; 9,11=50$ $\mu \mathrm{m}$. 
leg. R. Santesson\& R. Moberg P55: 75 (holotype: S!).

\section{Description}

Thallus brownish grey to orange, opaque, mat; yellowish grey with blackish margins under stereomicroscope. Lobes up to $6 \mathrm{~mm}$ wide, overlapping, attached in points, ascending; upper surface rugose to the naked eye, minutely bullate (not scrobiculate) under $20 \times$ magnification; apices rounded, revolute, smooth; lateral margin smooth, revolute, undulate; lower side light grey to yellow, rugose to the naked eye, pubescent and rugulose under $20 \times$ magnification. Isidia absent. Lobules rounded, $0.5 \mathrm{~mm}$ diam., unbranched, erect, firm, black to brown, casually distributed on the margin of apothecia and of some lobes, frequent. Thallus attached by hairs; rhizines absent; hapterons absent; hairs branched, $50 \mu \mathrm{m}$ long, cream, on both surfaces and amphithecium, abundant on lower side and frequent on upper side, usually with 6 cylindrical cells. Apothecia up to $3 \mathrm{~mm}$ diam., laminal, subpedicelate, disc concave to flattened; margin brown, smooth, lobulate; amphithecia yellow, smooth, hairy; corona absent; pedicel originated by the thalline exciple, short, pubescent.

\section{Anatomy}

Thallus 50-70 $\mu \mathrm{m}$ thick, quadratic cells of both cortices $5 \mu \mathrm{m}$ wide, columnar hyphae 2.5 $\mu \mathrm{m}$ thick, straight and inclined, 4 cells long, abundant. Cyanobacteria blue, abundant, filament with an indeterminate number of spherical cells 3.5-4.0 $\mu \mathrm{m}$ diam.; gelatinous matrix scarce, hyaline. Apothecia with hymenia 170-190 $\mu \mathrm{m}$ high, subhymenia yellow 10-20 $\mu \mathrm{m}$ thick; hypothecia hyaline 15-25 $\mu \mathrm{m}$ thick, annular colloplectenchymatous tissue; subhymenial paraplectenchymatous tissues absent; parahymenial tissues continuous to hypothecia, angular colloplectenchyma to paraplectenchyma at the apex, 20-30 $\mu \mathrm{m}(5 \mu \mathrm{m})$ thick at the base, 60-75 $\mu \mathrm{m}$ (10 cells) thick at the apex; thalline exciples $1 / 3$ of the hymenia height (with ornament on the apex), 35-40 $\mu \mathrm{m}$ (ca. 5 cells) thick at the base, 55-75 $\mu \mathrm{m}$ ( 6 cells) thick at the middle, $100-125 \mu \mathrm{m}$ (ca. 7 cells) thick at the base; basal paraplectenchymatous tissues absent. Ascospores fusiform, 25-32 × 7-13 $\mu \mathrm{m}, 5-6 \times 2-$ 4 cells, apices obtuse, muriform. Pycnidia absent.

\section{Comments}

Leptogium scrobiculatum is characterized by the relief of surface: it is the only hairy species that has a minutely bullate upper surface, not scrobiculate as the name suggest. The apothecium is composed by colloplectenchymatous hypothecium, colloplectenchymatous to paraplectenchymatous parahymenium and paraplectenchymatous thalline exciple. The apothecia and ascospores were not described in protologue, but they are present on holotype and are described here by the first time. The pedicel is originated by thalline exciple and the basal paraplectenchymatous tissue of the apothecium is absent.

\section{Acknowledgments}

M.J. Kitaura is grateful to FAPESP (2008/51072-3) for the PhD grant and M.P. Marcelli to $\mathrm{CNPq}$ for a research grant.

\section{References}

Awasthi DD, Akhtar P. 1977 - The genus Leptogium (sect. Mallotium) in India. Norwegian Journal of Botany 24, 59-71.

Canêz L, Marcelli MP. 2010 - The Punctelia microsticta-group (Parmeliaceae). The Bryologist 113(4), 728-738.

Cunha IPR. 2007 - Fungos liquenizados do gênero Leptogium (Ascomycetes) no litoral sul do Estado de São Paulo. Master thesis presented to Instituto de Biociências UNESP Universidade Estadual Paulista, Botucatu. 101p. 
Galloway DJ, Jørgensen PM. 1995 - The lichen genus Leptogium (Collemataceae) in Southern Chile, South America. In: Flechten Follmann - Contribution to Lichenology in Honour of Gerhard Follmann (eds FJA Daniels, M Schulz, J Peine). Published by the Geobotanical and Phytotaxonomical Study Group, Botanical Institute, University of Cologne, Germany 227247.

Jørgensen PM. 1973 - Über einige Leptogium-arten vom Mallotium-typ. Herzogia 2, 453-468.

Jørgensen PM. 1975 - Contributions to a monograph of the Mallotium-hair Leptogium species. Herzogia 3, 433-460.

Jørgensen PM. 1997 - Further notes on hairy Leptogium species. Symbolae Botanicae Upsalienses 32(1), 113-130.

Jørgensen PM. 2002 - Proposals to reject the name Collema proboscidale and to conserve the name Collema phyllocarpum with a conserved type, thereby stabilizing nomenclature of some tropical Leptogium species (Collemataceae, Lecanorales). Taxon 51(3), 567-568.

Jørgensen PM, Kashiwadani H. 2008 -Leptogium loriforme P. M. Jørg. \& Kashiw., a new hairy species from Papua New Guinea. Lichenologist 40(2), 123-125.

Jørgensen PM, Olley L. 2010 - A new hairy Leptogium from Nepal. Lichenologist 42(4), 387-389.

Jungbluth P, Marcelli MP, Klaus K. 2011 - A new species and a new record of Pyxine (Physciaceae) with norstictic acid from São Paulo State, Brazil. Mycotaxon 115, 435-442.

Kitaura MJ. 2012 - Estudos taxonômicos de Leptogium (Ach.) S.F. Gray (Collemataceae, fungos liquenizados). $\mathrm{PhD}$ thesis presented to Instituto de Biociências, UNESP, Universidade Estadual Paulista. Botucatu. 249p.

Kitaura MJ, Marcelli MP. 2012 - The Leptogium juressianum complex in southeastern Brazil. Mycotaxon 120, 215-221.

Kitaura MJ, Marcelli MP. 2013 - A revision of Leptogium species with spherical-celled hairs (section Mallotium p.p.). The Bryologist 116(1), 15-27.

McNeill J, Turland NJ, Barrie FR, Buck WR, Demoulin V, Greuter W, Hawksworth DL, Herendeen PS, Knapp S, Marhold K, Prado J, Prudd'homme van Reine WF, Smith GF, Wiersema JH. 2012 - International Code of Nomenclature for algae, fungi, and plants (Melbourne Code). Regnum Vegetabile 154, Koeltz Scientific Books.

Nylander W. 1861 - Additamentum Lichenographiam Andinum Boliviensium. Annalesdes Sciences Naturelles 15(4), 365-382.

Otálora MAG, Martínez I, Aragón G, Molina MC, Lutzoni F. 2010 - Disentangling the CollemaLeptogium complex through a molecular phylogenetic study of the Collemataceae (Peltigerales, lichen-forming Ascomycota). Mycologia 102, 279-290.

Sierk HA. 1964 - The genus Leptogium in North America north of Mexico. The Bryologist 67, 245-317.

Swinscow TDV, Krog H. 1988 - Macrolichens of East Africa. British Museum (Natural History). London 128-148. 